\section{Response of Onion Yield, Grade, and Financial Return to Plant Population and Irrigation System}

\author{
Clinton C. Shock ${ }^{1,3}$, Erik B.G. Feibert ${ }^{2}$, Alicia Riveira, \\ and Lamont D. Saunders \\ Oregon State University Malheur Experiment Station, 595 Onion Avenue, \\ Ontario, OR 97914
}

Additional index words. Allium cepa, subsurface drip irrigation, furrow irrigation, soil water tension, irrigation criteria

\begin{abstract}
Onion (Allium cepa) plant population is an important factor in total yield and bulb size, both of which can influence economic return to growers. Different onion bulb marketing opportunities influence the plant populations that growers should target. With the transition from furrow irrigation to a drip irrigation system, growers have doubts as to the onion population that should be planted to assure favorable economic outcomes. Onions were grown on silt loam at the Oregon State University Malheur Experiment Station, Ontario, OR in 2011 and 2012 following bread wheat (Triticum aestivum L.) each year. Long-day onion cultivars Vaquero, Esteem, Barbaro, and Sedona were planted heavily and thinned to nominal plant populations between 222,000 and 593,000 plants/ha under furrow irrigation, subsurface drip irrigation, and "intense bed" subsurface drip irrigation. The intense bed configuration had 50\% more rows of onions with three drip tapes per 1.94-m bed instead of two tapes. The experiment had a randomized complete block split-split-plot design with six replicates. Irrigation systems were the main plots, cultivars the split plots, and plant populations the split-split plots. Onion yield and grade responses to plant population for each cultivar and each planting system were determined by regression of yield and grade on the actual onion plant stands. In general, there were few differences among irrigation systems or interactions among irrigations systems, cultivars, and plant populations. Averaging over cultivars, total and marketable bulb yield out of storage increased with plant population, whereas the bulb diameters

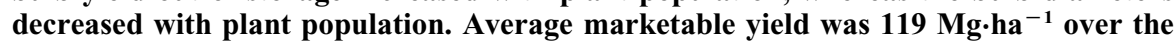
2 years. Average yield of colossal bulbs $>102 \mathrm{~mm}$ in diameter decreased with increasing plant population. In 2011, estimated gross economic return increased linearly with plant population, offset in part by increasing seed cost. In 2012, estimated economic return responded quadratically to plant population with maximum return of $\$ 45,357 / \mathrm{ha}$ at 419,000 plants/ha.
\end{abstract}

About 8000 ha of onions (Allium cepa) are grown in the Treasure Valley located in eastern Oregon and southwestern Idaho of the United States. These onions are mostly longday cultivars and are marketed from August from the field and continuing to April from storage (Shock et al., 2000b). Before the mid$1990 \mathrm{~s}$, jumbo size onions (76 to $102 \mathrm{~mm}$ ) were the most valuable size class in the Treasure Valley. Shock et al. (1990) demonstrated that marketable $(>57 \mathrm{~mm})$ and jumbo yields of long-day onions were maximized at 93 and $78 \mathrm{Mg} \cdot \mathrm{ha}^{-1}$, respectively, by a plant population of 385,000 plants. $\mathrm{ha}^{-1}$ in the

Received for publication 21 Apr. 2015. Accepted for publication 12 June 2015 .

This project was funded by the Idaho EasternOregon Onion Committee, Oregon State University, Formula Grant no. 2014-31100-06041 and Formula Grant no. 2014-31200-06041 from the USDA National Institute of Food and Agriculture, and onion seed companies.

${ }^{1}$ Professor and Director.

${ }^{2}$ Senior Faculty Research Assistant.

${ }^{3}$ Corresponding author. E-mail: clinton.shock@ oregonstate.edu. highest with 800,000 plants/ha compared with 400,000 and $1,000,000$ plants/ha (Hatridge-Esh and Bennett, 1980).

Some of the studies of onion yield responses to plant population have been based on the rectangularity, the ratio of interrow to intrarow spacing. Uniform rectangularities of 2 in Frappell (1973), of 1.8 in Hatridge-Esh and Bennett (1980), and of less than 6 in Rickard and Wickens (1979) were used across all plant populations by varying row spacings. Rumpel and Felzczynski (2000) used a row spacing of $0.27 \mathrm{~m}$. Rogers (1978) used rectangularities varying from 1 to 26 as plant population increased. Both Frappell (1973) and Hatridge-Esh and Bennett (1980) found that increasing rectangularity was correlated with decreasing bulb yield.

With the advent of new cultivars and adoption of drip irrigation, a reevaluation of onion plant populations for the Treasure Valley was encouraged by onion packers. The most common onion planting configuration used in the Treasure Valley, named locally "conventional bed" has 1.94-m or slightly narrower beds with two drip tapes and four double rows of onions. An alternative planting configuration, "intense bed," has beds of similar width with three drip tapes and six double rows of onions, hence lower rectangularity. Growers in the Treasure Valley of Oregon and Idaho who deliver onions on a contract want to be able to plan their plantings for adequate return based on the size and price stipulations of the contract. The objective of the trials reported here was to evaluate the yield response of four onion cultivars to plant populations under furrow irrigation and with two planting configurations under drip irrigation.

\section{Materials and Methods}

Onions were grown in 2011 and 2012 on an Owyhee silt loam (coarse silty, mixed, mesic Xerollic Camborthid) at the Oregon State University Malheur Experiment Station, Ontario, OR. The fields had previously been planted to bread wheat (Triticum aestivum L.). The wheat stubble was shredded and the field deep-chiseled, disked, irrigated, moldboard plowed, roller harrowed, and bedded in the fall before spring planting. Each year, before fall plowing, fertilizer was broadcast based on soil analyses and according to extension guidelines (Sullivan et al., 2001). The soil had a $\mathrm{pH}$ of 8.0 and $1 \%$ organic matter in 2011 and a pH of 7.7 and $1.7 \%$ organic matter in 2012 . In 2011, phosphorus (P) at $224 \mathrm{~kg} \cdot \mathrm{ha}^{-1}$, sulfur (S) at $90 \mathrm{~kg} \cdot \mathrm{ha}^{-1}$, manganese $(\mathrm{Mn})$ at 8 $\mathrm{kg} \cdot \mathrm{ha}^{-1}$, and boron (B) at $1.12 \mathrm{~kg} \cdot \mathrm{ha}^{-1}$ were broadcast. In 2012, P at $112 \mathrm{~kg} \cdot \mathrm{ha}^{-1}, \mathrm{~S}$ at $224 \mathrm{~kg} \cdot \mathrm{ha}^{-1}$, gypsum at $1120 \mathrm{~kg} \cdot \mathrm{ha}^{-1}$, and $\mathrm{B}$ at $1.12 \mathrm{~kg} \cdot \mathrm{ha}^{-1}$ were broadcast. In 2011 , at fall bedding, the field was fumigated with $187 \mathrm{~L} \cdot \mathrm{ha}^{-1}$ of Telone C-17 (77.9\% 1,3-dichloropropene $+16.5 \%$ chloropicrin, Dow AgroSciences, Indianapolis, IN). In 2012 at fall bedding, the field was fumigated with $140 \mathrm{~L} \cdot \mathrm{ha}^{-1}$ of Vapam $(42 \%$ 
sodium methyldithiocarbamate; Amvac, Los Angeles, CA). After fumigation, the fields were left until spring without further tillage.

Experimental design. The experiments had randomized complete block designs with split-split plots and six replicates. The main plots were the three irrigation treatments: "conventional bed" drip irrigation, "intense bed" drip irrigation, and "conventional bed" furrow irrigation. The field was divided into irrigation main plots that were $2.24 \mathrm{~m}$ wide by $42 \mathrm{~m}$ long. Each irrigation main plot was divided into four split plots that were $10 \mathrm{~m}$ long. Each split plot in each irrigation main plot was planted to one of four cultivars ('Vaquero', Bayer CropScience, Parma, ID; 'Barbaro', Seminis, Inc. Monsanto Co., Payette, ID; 'Sedona', Bejo Seeds, Inc., Oceano, CA; 'Esteem', Crookham Co., Caldwell, ID) on 7 Apr. 2011 and on 12 Mar. 2012. Each cultivar split plot was then divided into four population split-split plots in 2011 and five population split-split plots in 2012.

Irrigation systems. "Intense bed" drip irrigation is a local name used for beds with three drip tapes and six double rows of onions, whereas "conventional bed" drip irrigation is a local name used for beds with two drip tapes and four double rows of onions, roughly retaining the planting configurations used with furrow-irrigated onion. In the conventional drip and furrow irrigation plots, the double rows were centered $0.56 \mathrm{~m}$ apart (four double rows on a 1.94-m bed: 2.24-m tractor pass). In the intense bed drip plots, the double rows were spaced $0.336 \mathrm{~m}$ apart (six double rows on a $1.94-\mathrm{m}$ bed: $2.24-\mathrm{m}$ tractor pass).

In the conventional drip and furrowirrigated plots, tape (Toro Aqua-Traxx, Toro Co., El Cajon, CA) with emitters spaced $0.3 \mathrm{~m}$ apart and an emitter flow rate of 0.5 $\mathrm{L} \cdot \mathrm{h}^{-1}$ was laid at $0.1-\mathrm{m}$ depth between two double rows at the same time as planting (two tapes on a $2.24-\mathrm{m}$ pass, $1.1 \mathrm{~m}$ between tapes on 1.94-m beds). After onion establishment, the furrow irrigation system was installed. In the intense bed drip plots, tape (Toro AquaTraxx) with emitters spaced $0.2 \mathrm{~m}$ apart and flow rate of $0.25 \mathrm{~L} \cdot \mathrm{h}^{-1}$ was laid at $0.1-\mathrm{m}$ depth before planting (three tapes on a 2.24-m tractor pass, $0.55 \mathrm{~m}$ between tapes on $1.94-\mathrm{m}$ beds). Different tapes were used so that the irrigation duration would be similar between the drip irrigation treatments.

Onion planting. Onion seed was planted in double rows at $60 \mathrm{seeds} / \mathrm{m}$ of single row.
Although growers in the Treasure Valley direct seed to stand, seed was planted in excess and plants were thinned to the designed plant populations. Planting was done with customized John Deere Flexi Planter units equipped with disc openers. Immediately after planting, plots received $138 \mathrm{~g} \cdot \mathrm{ha}^{-1}$ of chlorpyrifos to control onion maggot (Delia antiqua). Onion emergence started on 26 Apr. 2011 and on 2 Apr. 2012. On 9 June 2011 and on 14 May 2012, alleys $0.92 \mathrm{~m}$ wide were cut between the cultivar split plots, leaving plots $9.2 \mathrm{~m}$ long.

Onion plant populations. Each split-split plot was $1.8 \mathrm{~m}$ long. On 10 June 2011 and on 15 May 2012, the seedlings in each split-split plot of each cultivar split plot were hand thinned to a designated plant population (Table 1) ranging from 220,000 to 590,000 plants/ha. Wider in row spacings were used for the intense bed irrigation system to have comparable plant populations between the irrigation systems. The 222,000 plants/ha treatment was not used in 2011. Plant population "approximate rectangularities" were calculated based on the average distance between the individual rows of onions and the distance between the onions in each individual row (Table 1). The calculated rectangularities were approximate since the distance between the pairs of rows was greater than the distance between the row pairs. After thinning, the drip tape in the furrow irrigation plots was removed and the furrows between onion rows were cultivated to allow for furrow irrigation.

Cultural practices. The onions were managed to minimize yield reductions from weeds, pests, diseases, water stress, and nutrient deficiencies. Weeds were controlled with conventional low rate herbicide applications as needed until early July, when onion foliage growth precluded further tractor traffic. Herbicides used included bromoxynil, oxyfluorfen, sethoxydim, and pendimethalin. They were applied according to product labels. Thrips were controlled from June through early August with weekly applications of insecticides that included spirotetramat, spinetoram, and methomyl.

Based on root tissue analysis, a total of $174 \mathrm{~kg} \cdot \mathrm{ha}^{-1}$ of nitrogen $(\mathrm{N}), 45 \mathrm{~kg} \cdot \mathrm{ha}^{-1}$ of potassium $(\mathrm{K}), 5.6 \mathrm{~kg} \cdot \mathrm{ha}^{-1}$ of magnesium $(\mathrm{Mg})$, and $0.45 \mathrm{~kg} \cdot \mathrm{ha}^{-1}$ of $\mathrm{B}$ were applied during the 2011 season. Based on root tissue analysis, a total of $165 \mathrm{~kg} \cdot \mathrm{ha}^{-1}$ of $\mathrm{N}, 5.6$ $\mathrm{kg} \cdot \mathrm{ha}^{-1}$ of $\mathrm{Mg}, 5.6 \mathrm{~kg} \cdot \mathrm{ha}^{-1}$ of calcium (Ca), and $0.45 \mathrm{~kg} \cdot \mathrm{ha}^{-1}$ of $\mathrm{B}$ were applied during the 2012 season. The nutrients were injected through the drip tape or water run during irrigations in the furrow-irrigated plots.

Onions in each conventional and intense bed drip main plot were irrigated automatically and independently to maintain the soil water tension (SWT) in the onion root zone below $20 \mathrm{kPa}$ (Shock et al., 2000a). Soil water tension was measured in each main plot with four granular matrix sensors (GMS, Watermark Soil Moisture Sensors Model 200SS; Irrometer Co., Riverside, CA) installed at $0.2-\mathrm{m}$ depth in the center of a double row. Sensors had been calibrated to SWT (Shock et al., 1998a). The GMS were connected to a data logger via multiplexers (AM 410 multiplexer; Campbell Scientific, Logan, UT). The data logger read the sensors and recorded the SWT every hour. The data logger made irrigation decisions independently for each drip-irrigated main plot every $12 \mathrm{~h}$. The individual irrigation decisions for each plot were based on the average SWT. The irrigation durations were $8 \mathrm{~h}, 19 \mathrm{~min}$ for the conventional drip system and $7 \mathrm{~h}, 10 \mathrm{~min}$ for the intense bed drip system to supply $12 \mathrm{~mm}$ of water per irrigation. The irrigations were controlled by the data logger using a controller (SDM CD16AC controller; Campbell Scientific, Logan, UT) connected to solenoid valves in each plot. The amount of water applied to each plot was recorded daily at 8:00 AM from a water meter installed between the solenoid valve and the drip tape. The automated irrigation system was started on 1 July and ended on 9 Sept. in 2011 and was started on 16 June and ended on 5 Sept. in 2012. Onion evapotranspiration $\left(\mathrm{ET}_{\mathrm{c}}\right)$ was calculated with a modified Penman equation (Wright, 1982) using data collected at the Malheur Experiment Station by an AgriMet weather station. Onion $\mathrm{ET}_{\mathrm{c}}$ was estimated and recorded from crop emergence until the onions were lifted.

The furrow-irrigated onions were irrigated manually when the SWT at $0.2-\mathrm{m}$ depth reached $25 \mathrm{kPa}$ (Shock et al., 1998b). The field in which the 2011 trial was conducted had poor lateral soil hydraulic conductivity. The field in which the 2012 trial was conducted had $1 \%$ to $3 \%$ slope. To reduce erosion and improve the lateral movement of water during furrow irrigations, straw at $1000 \mathrm{~kg} \cdot \mathrm{ha}^{-1}$ was applied to the furrow bottoms in late May each year (Shock et al., 1999). The last furrow irrigation was on 29 Aug. in 2011 and on 31 Aug. in 2012.

Onion harvest and evaluations. The onions were lifted on 13 Sept. in 2011 and 2012 to field cure. Onions from $1.5 \mathrm{~m}$ of the middle

Table 1. Target spacing between onion seedlings in single row after thinning, plant density, and approximate rectangularity (average interrow/intrarow spacing) for plant populations ranging from 222,000 to 592,000 plants/ha. The average inter-row spacings from the middle of the wheel tracks on either side of the bed were $0.255 \mathrm{~m}$ for the conventional bed and $0.183 \mathrm{~m}$ for the intense bed.

\begin{tabular}{|c|c|c|c|c|c|}
\hline \multirow{2}{*}{$\begin{array}{l}\text { Plant population } \\
\text { (plants/ha) }\end{array}$} & \multicolumn{2}{|c|}{ Spacing in single row } & \multicolumn{2}{|c|}{ Rectangularity (avg interrow/intrarow spacing) } & \multirow[b]{2}{*}{ Plant density (plants $/ \mathrm{m}^{2}$ ) } \\
\hline & Conventional bed (mm) & Intense bed $(\mathrm{mm})$ & Conventional bed & Intense bed & \\
\hline 222,222 & 160 & 241 & 1.7 & 0.8 & 22.3 \\
\hline 296,296 & 121 & 181 & 2.3 & 1.0 & 29.7 \\
\hline 395,062 & 90 & 137 & 3.1 & 1.4 & 39.6 \\
\hline 493,827 & 73 & 109 & 3.8 & 1.7 & 48.9 \\
\hline 592,593 & 60 & 90 & 4.7 & 2.1 & 59.2 \\
\hline
\end{tabular}


two double rows in each conventional drip and furrow irrigation split-split plot and from $1.5 \mathrm{~m}$ of the middle four double rows in each intense bed drip split-split plots were topped by hand and bagged on 21 Sept. 2011 and on 24 Sept. 2012. Onions were graded in early October each year.

During grading, all bulbs from each splitsplit plot were counted. After counting, the bulbs were separated according to quality: bulbs without blemishes (No. 1s), split bulbs (No. 2s), neck rot (bulbs infected with the fungus Botrytis allii in the neck or side), plate rot (bulbs infected with the fungus Fusarium oxysporum f. sp. cepae), and black mold (bulbs infected with the fungus Aspergillus niger). The No. 1 bulbs were graded mechanically (Kerian Speed Sizer; Kerian Machines, Inc., Grafton, ND) according to diameter: small $(<57 \mathrm{~mm})$, medium $(57-76 \mathrm{~mm})$, jumbo (76-102 mm), colossal (102-108 $\mathrm{mm})$, and super colossal ( $>108 \mathrm{~mm})$. Bulb counts per $23 \mathrm{~kg}$ of super colossal onions were determined for each plot of every cultivar by weighing and counting all super colossal bulbs during grading. Marketable yield consisted of No.1 bulbs larger than 57 $\mathrm{mm}$. After grading, 25 bulbs from each plot were separated and individually measured for diameter.

Data were analyzed with analysis of variance and regression analysis (NCSS, Kaysville, UT). Treatment differences were compared using regression analysis (on all the data, not treatment averages) where the independent variable was the actual plant population in each split-split plot based on the actual bulb counts during grading.

Gross economic returns were calculated by crediting each marketable onion size class with the average prices paid to the grower. Onion prices each year were the average over the marketing season from October through March. Onion prices were obtained from the USDA Agricultural Statistics Service and reflect adjustments for packing and shipping costs. In the 2011-12 season, onion prices were $\$ 195,121,66$, and 65 per $\mathrm{Mg}$ for super colossal, colossal, jumbo, and medium bulbs, respectively. In the 2012-13 season, onion prices were $\$ 504,437,381$, and 269 per $\mathrm{Mg}$ for super colossal, colossal, jumbo, and medium bulbs, respectively. Packing houses in the Treasure Valley have had difficulty marketing super colossal bulbs due to a diminished market. In spite of the prices in 2011 and 2012, super colossal bulbs have been largely sold at the same price as colossal bulbs over the last 3 years. In the calculation of total gross returns, super colossal bulbs were credited with the same price as colossal bulbs to reflect current market conditions. Prices for pelleted long-day hybrid onion seed were based on market prices in May 2015.

\section{Results}

Despite the application of straw to the furrow bottoms, intense bed drip and conventional drip irrigation resulted in more uniform soil moisture over time than furrow irrigation (Fig. 1). From onion emergence to the last irrigation, 744 and $914 \mathrm{~mm}$ of water were applied to the conventional drip irrigation plots in 2011 and 2012, respectively. Totals of 734 and $841 \mathrm{~mm}$ of water were applied to the intense bed drip irrigation plots in 2011 and 2012, respectively. Furrowirrigated onion received $\approx 1370 \mathrm{~mm}$ each year. Onion $\mathrm{ET}_{\mathrm{c}}$, measured from emergence to the last irrigation, totaled $765 \mathrm{~mm}$ in 2011 and $942 \mathrm{~mm}$ in 2012. Onion yields and size were lower in 2011 than in 2012. 2012 was warmer with 1427 growing degree days (10 to $30{ }^{\circ} \mathrm{C}$ ) compared with 1182 growing degree days in 2011.

In 2011, neither irrigation system nor the interaction between irrigation system, plant population, and cultivar were significant factors affecting any yield category, except for small bulb yield (Table 2). In 2011, all the other yield categories were only affected by plant population. In 2012, there was a significant effect of irrigation system on colossal plus super colossal yield and medium yield. In 2012, the interaction of irrigation by cultivar was significant for all yield categories, except the yield of medium and small bulbs.

Despite the high seeding rate, lack of uniform emergence resulted in the actual plant populations for the highest plant population treatment being lower than planned. The actual highest plant populations averaged over cultivars in 2011 were 507,000, 524,000 , and 510,000 plants/ha for the intense bed drip, conventional bed drip, and furrow irrigation systems, respectively. In 2012, the highest actual plant populations were $523,000,457,000$, and 426,000 plants/ ha for the intense bed drip, conventional bed drip, and furrow irrigation systems, respectively.

In 2011, total yield, marketable yield, medium bulb yield, and small bulb yield increased with increasing plant population up to $118,113,25$, and $6 \mathrm{Mg} \cdot \mathrm{ha}^{-1}$, respectively, at the highest population tested $(514,000$ plants/ha) averaged over all cultivars and all irrigation systems (Fig. 2A and B). In 2011, yield of bulbs larger than $102 \mathrm{~mm}$ (colossal plus super colossal bulbs) decreased with increasing plant population for 'Vaquero', 'Barbaro', and 'Sedona' under all irrigation systems (data not shown). The decrease for 'Esteem' was not statistically significant under any irrigation system. In 2011, jumbo yields showed weak or no response to plant population for all cultivars under all irrigation systems, except for 'Vaquero' and 'Barbaro' under conventional bed drip irrigation. 'Vaquero' and 'Barbaro' showed a positive linear response of jumbo yield to plant population under conventional bed drip irrigation.

In 2012, total yield and marketable yield for all cultivars under all irrigation systems increased linearly with increasing plant population, except 'Vaquero', 'Sedona', and 'Esteem' under intense bed drip (data not shown). Total yield and marketable yield for 'Vaquero' and 'Esteem' under intense bed
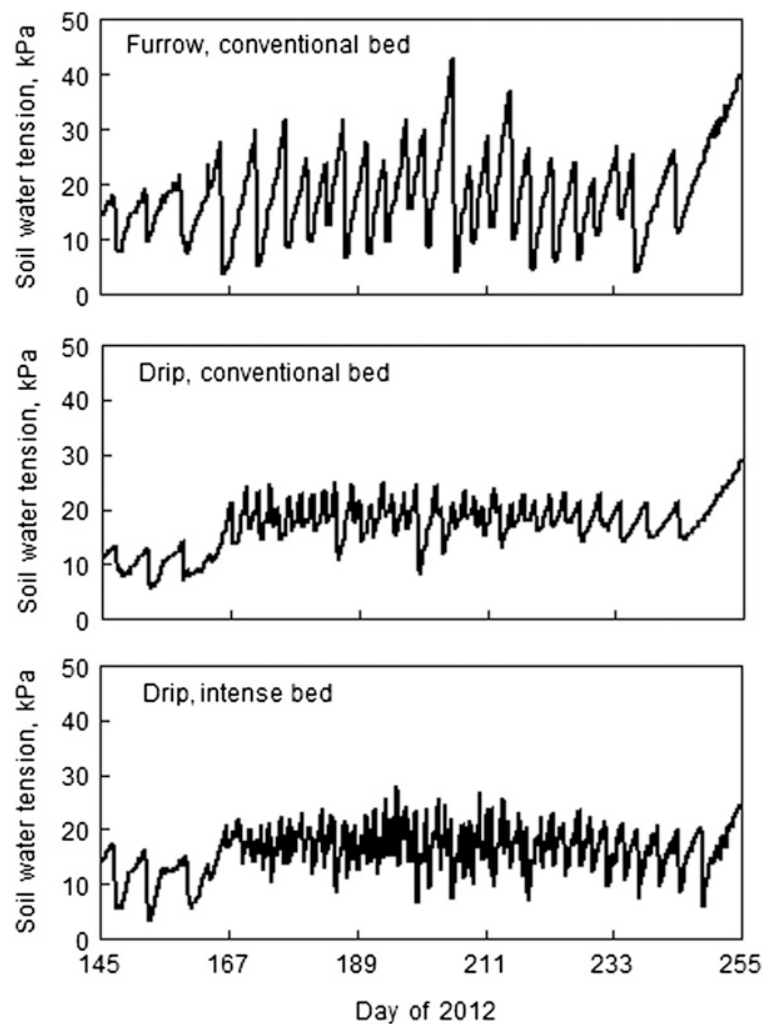

Fig. 1. Soil water tension over time for three irrigation systems in onions. Oregon State University, Malheur Experiment Station, Ontario, OR. 
Table 2. Analysis of variance ( $P$ values) for the effect of five plant populations (four in 2011) on onion yield under three irrigation systems for four cultivars.

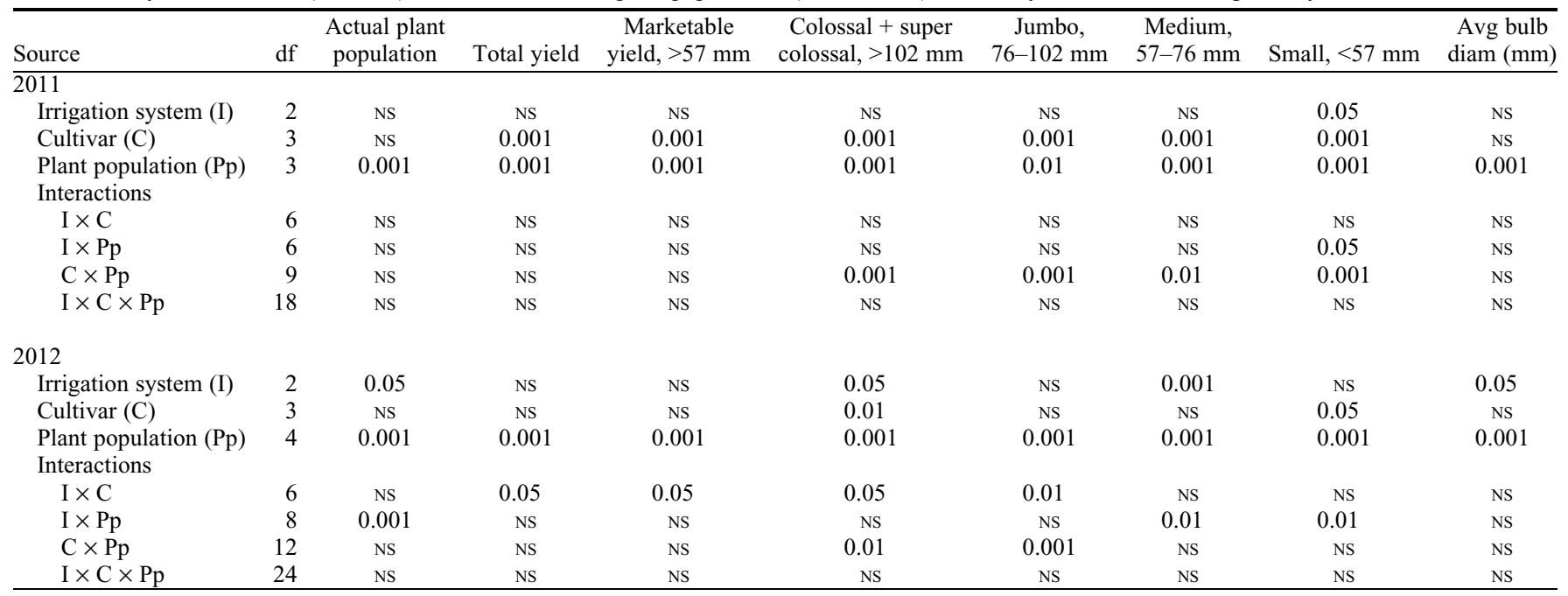

NS $=$ Not statistically significant.
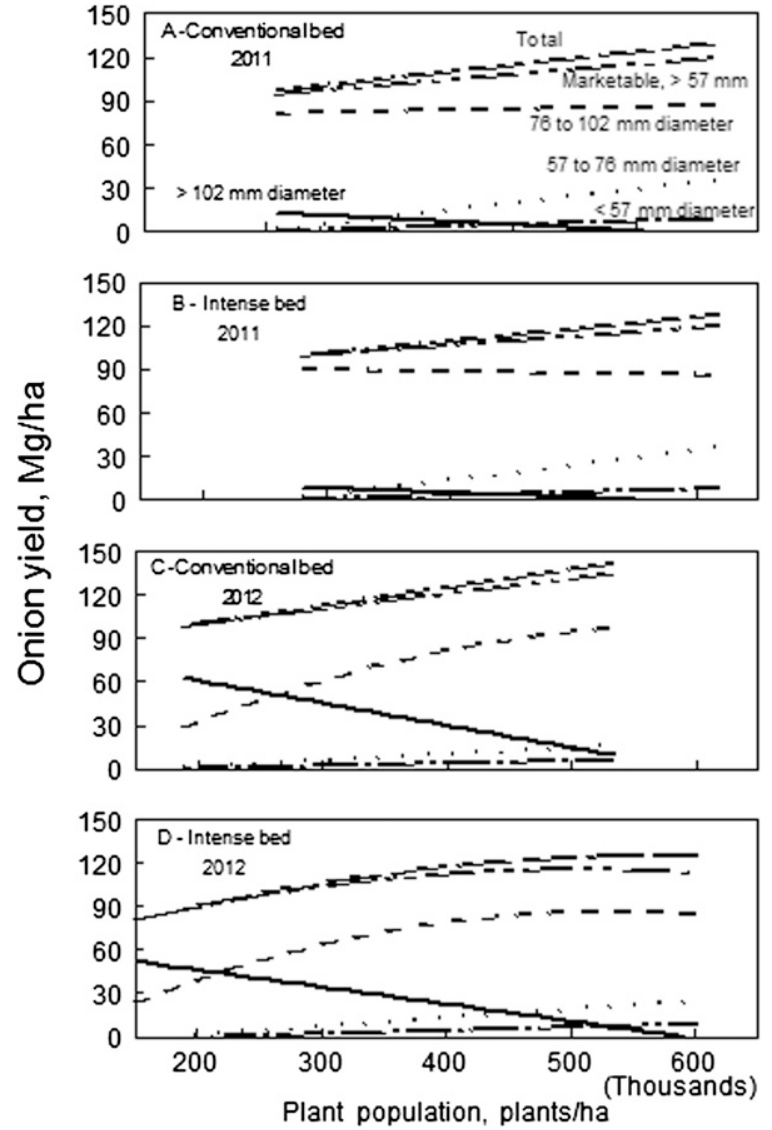

Fig. 2. Onion yield and yield by bulb diameter responses to plant population for onions grown at Ontario, OR on (A) a conventional bed configuration averaged over drip and furrow irrigation and four cultivars in 2011; (B) an intense bed configuration under drip irrigation averaged over four cultivars in 2011 ; (C) a conventional bed configuration averaged over drip and furrow irrigation and four cultivars in 2012; and (D) an intense bed configuration under drip irrigation averaged over four cultivars in 2012 .

drip showed quadratic responses to plant population. Marketable yield for 'Sedona' had no significant response to plant population. For 'Vaquero' under intense bed drip, maximum total yield of $133 \mathrm{Mg} \cdot \mathrm{ha}^{-1}$ was achieved with 518,000 plants/ha and the maximum marketable yield of $126 \mathrm{Mg} \cdot \mathrm{ha}^{-1}$ was achieved with 488,000 plants/ha. For 'Esteem' under intense bed drip, maximum total yield of $113 \mathrm{Mg} \cdot \mathrm{ha}^{-1}$ was achieved with 484,000 plants/ha and the maximum marketable yield of $107 \mathrm{Mg} \cdot \mathrm{ha}^{-1}$ was achieved with 432,000 plants/ha. Jumbo yields under intense bed were maximized at $99,96,73$, and
$83 \mathrm{Mg} \cdot \mathrm{ha}^{-1}$ by $621,000,542,000,417,000$, and 437,000 plants/ha for 'Vaquero', 'Barbaro', 'Sedona', and 'Esteem', respectively. For the conventional bed system, jumbo yields showed quadratic responses to plant population for 'Vaquero' under furrow irrigation (maximum yield outside of the range of populations tested) and 'Esteem' under drip irrigation (maximum of $89 \mathrm{Mg} \cdot \mathrm{ha}^{-1}$ at 473,000 plants/ha). Jumbo yields for 'Barbaro', 'Sedona', and 'Esteem' under furrow irrigation and for 'Vaquero', 'Barbaro', and 'Sedona' under conventional bed drip irrigation increased with increasing plant population up to the highest tested of 426,000 plants/ha for conventional bed furrow irrigation and 457,000 plants/ha for conventional bed drip irrigation. Medium and small bulb yields for all cultivars under all irrigation systems increased with increasing plant population, except for medium bulb yield of 'Sedona' under intense bed drip. For 'Sedona' under intense bed drip, maximum medium yield was achieved at $18 \mathrm{Mg} \cdot \mathrm{ha}^{-1}$ with 500,000 plants/ha.

Responses based on all varieties. In 2011, averaged over cultivars, total yield, marketable yield, medium bulb yield, and small bulb yield increased to $118,113,25$, and 6 $\mathrm{Mg} \cdot \mathrm{ha}^{-1}$, respectively, with increasing plant population up to the highest tested of 514,000 plants/ha for all irrigation systems and bed configurations tested (Table 3; Fig. 2A and B). In 2012, averaged over cultivars, total yield, marketable yield, medium bulb yield, and small bulb yield increased to 131,126 , 12 , and $5 \mathrm{Mg} \cdot \mathrm{ha}^{-1}$, respectively, with increasing plant population up to the highest tested (443,000 plants/ha) for furrow and drip irrigation under the conventional bed system (Table 4; Fig. 2C). For drip irrigation under the intense bed system, total yield and marketable yield showed quadratic responses to plant population in 2012 (Fig. 2D). Under the intense bed system in 2012, maximum total yield was achieved at $125 \mathrm{Mg} \cdot \mathrm{ha}^{-1}$ with 580,169 plants/ha and maximum marketable 
Table 3. Regression parameters for onion yield categories in response to plant population under three irrigation systems over four cultivars in 2011 in Ontario, OR.

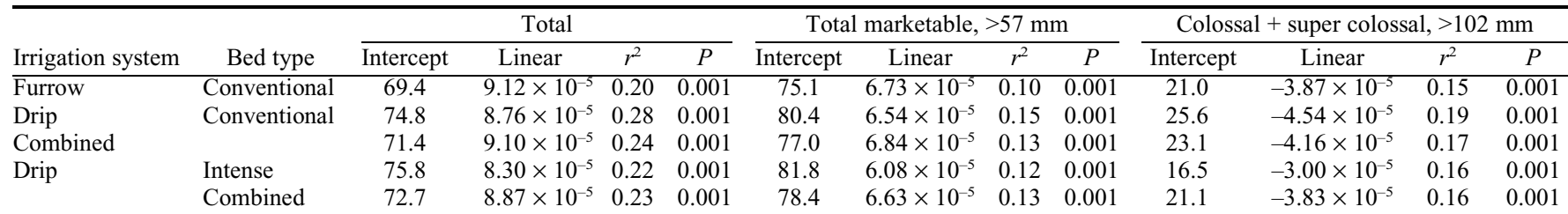

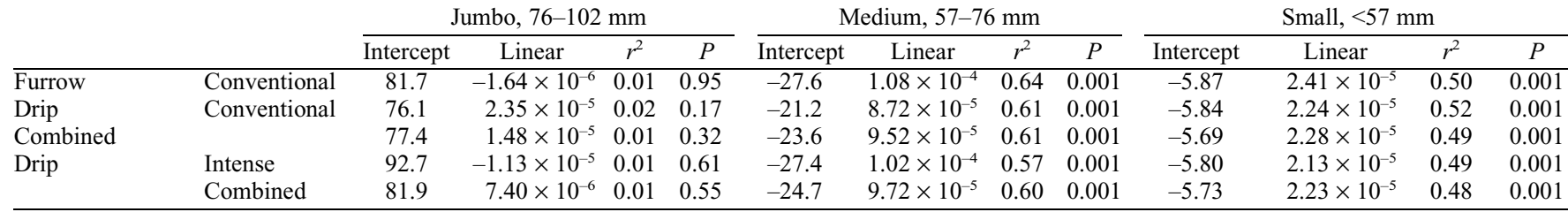

Table 4. Regression parameters for onion yield categories in response to plant population under three irrigation systems over four cultivars in 2012 in Ontario, OR.

\begin{tabular}{|c|c|c|c|c|c|c|c|c|c|c|c|c|c|c|}
\hline \multirow{2}{*}{$\begin{array}{l}\text { Irrigation } \\
\text { system }\end{array}$} & \multirow[b]{2}{*}{ Bed type } & \multicolumn{4}{|c|}{ Total } & \multicolumn{5}{|c|}{ Total marketable, $>57 \mathrm{~mm}$} & \multicolumn{4}{|c|}{ Colossal + super colossal, >102 mm } \\
\hline & & Intercept & Linear & Quadratic & $R^{2}$ & Intercept & Linear & Quadratic & $R^{2}$ & $P$ & Intercept & Linear & $\overline{R^{2}}$ & $P$ \\
\hline Drip & Conventional & 78.2 & $1.19 \times 10^{-4}$ & & 0.330 .001 & 81.4 & $9.99 \times 10^{-5}$ & & 0.25 & 0.001 & 9.8 & $-1.53 \times 10^{-4}$ & 0.28 & 0.001 \\
\hline \multirow{2}{*}{ Drip } & Com & 4.3 & $3.17 \times 10^{-4}$ & -3.00 & 0.260 .001 & 44.5 & $3.18 \times 10^{-4}$ & -3 . & 0.18 & 0.001 & 86.8 & $1.48 \times 10^{-4}$ & 0.28 & 0.001 \\
\hline & & \multicolumn{4}{|c|}{ Jumbo, 76-102 mm } & \multicolumn{5}{|c|}{ Medium, $57-76 \mathrm{~mm}$} & \multicolumn{4}{|c|}{ Small, $<57 \mathrm{~mm}$} \\
\hline Drip & Conventional & -46.7 & $4.74 \times 10^{-4}$ & $3.83 \times$ & 0.650 .001 & -7.1 & $4.33 \times 10^{-5}$ & & 0.52 & 0.001 & -3.0 & $1.69 \times 10^{-5}$ & 0.57 & 0.001 \\
\hline Combined & & -46.3 & $4.75 \times 10^{-4}$ & $-3.87 \times 10^{-10}$ & 0.580 .001 & -7.7 & $4.46 \times 10^{-5}$ & & 0.51 & 0.001 & -3.1 & $1.71 \times 10^{-5}$ & 0.54 & 0.001 \\
\hline \multirow[t]{2}{*}{ Drip } & Inten & -35.2 & $4.60 \times 10^{-4}$ & $-4.36 \times 10^{-10}$ & 0.560 .001 & -10.5 & $5.86 \times 10^{-5}$ & & 0.75 & 0.001 & -4.7 & $2.22 \times 10^{-5}$ & 0.58 & 0.001 \\
\hline & Combined & -54.2 & $5.45 \times 10^{-4}$ & $-5.19 \times 10^{-10}$ & 0.570 .001 & -10.0 & $5.35 \times 10^{-5}$ & & 0.64 & 0.001 & -3.9 & $1.97 \times 10^{-5}$ & 0.57 & 0.001 \\
\hline
\end{tabular}

yield was achieved at $115 \mathrm{Mg} \cdot \mathrm{ha}^{-1}$ with 507,463 plants/ha. In 2012, marketable yield, averaged over cultivars and irrigation systems, was maximized at $121 \mathrm{Mg} \cdot \mathrm{ha}^{-1}$ by 478,916 plants/ha.

Average bulb diameter decreased with increasing plant population for both planting configurations in both years (Fig. 3). The decrease in bulb size with plant population was nearly identical between planting configurations in 2011 and was nearly identical between planting configurations again in 2012.

In 2011, gross returns were responsive to plant population for 'Sedona' and 'Esteem' under conventional bed drip and for 'Esteem' under intense bed drip, all showing positive linear responses (data not shown). In 2012, 'Barbaro' under conventional bed furrow irrigation, and 'Barbaro', and 'Sedona' under conventional bed drip showed positive linear responses of gross returns to plant population. In 2012, 'Vaquero' under conventional bed drip and 'Vaquero' and 'Esteem' under intense bed drip showed quadratic responses of gross returns to plant population. Maximum gross returns of $\$ 55,600 /$ ha were achieved with 388,000 plants/ha for 'Vaquero' under conventional bed drip irrigation in 2012. Maximum gross returns for 'Vaquero' under intense bed drip irrigation of $\$ 47,300 /$ ha were achieved with 442,000

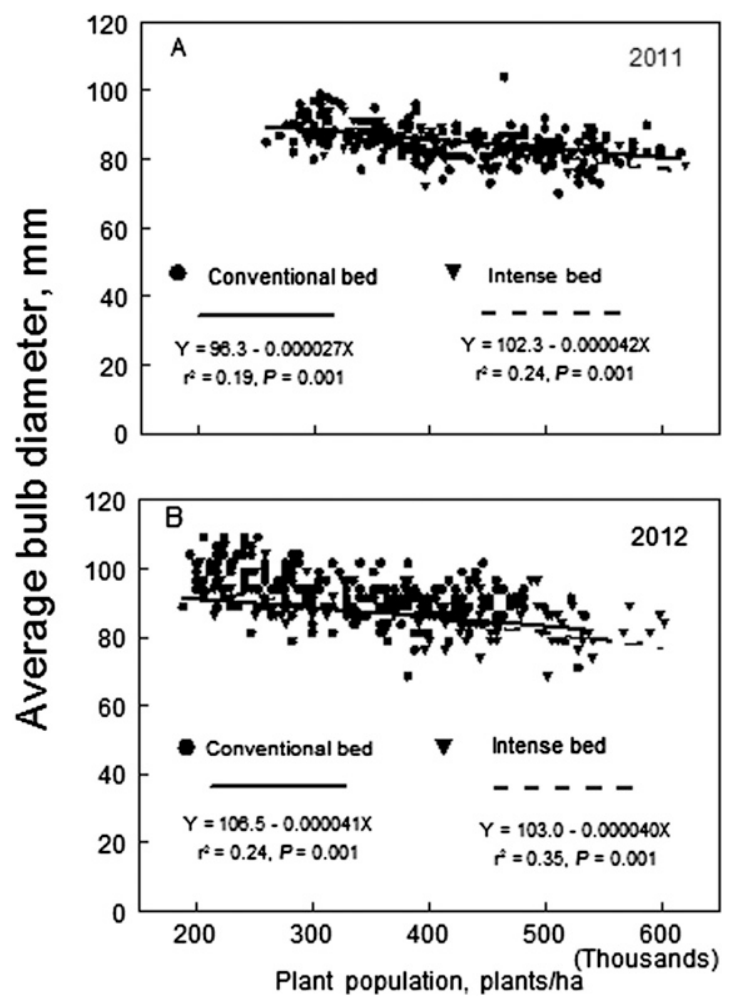

Fig. 3. Bulb diameter response to plant population for onions grown on conventional and intense bed configurations and four cultivars in 2011 and 2012 at Ontario, OR. The responses to plant populations on the conventional bed configurations were averaged over both drip and furrow irrigation systems. 
plants/ha and for 'Esteem' under intense bed drip irrigation maximum gross returns of $\$ 39,900 /$ ha were achieved with 400,000 plants/ha in 2012. Onion prices were atypically high in 2012.

The response of gross returns to plant population analyzed over all cultivars was weak in both 2011 and 2012 (data not shown). Analyzed over all cultivars and all irrigation systems, the response of gross returns to plant population was also weak for both years. Analyzed over all cultivars and all irrigation systems, the response of gross returns to plant population was positive linear in 2011 and quadratic in 2012 with a maximum gross return of $\$ 45,400 /$ ha at 419,000 plants/ha in 2012 (Fig. 4). The principle variable cost with increased plant population and direct seeding is the cost of seed. In 2011, the financial return to increased plant population was offset by the cost of additional onion seed (Fig. 4). Treated, pelleted, long-day hybrid onion seed averages $\$ 300 / 100,000$ seeds and results in $\approx 90,000$ plants. In 2012, the financial return to increased plant population was more than offset by the cost of additional onion seed.

\section{Discussion}

The lack of a difference in total and marketable yield between intense bed and conventional bed drip irrigation could be related to the good lateral soil water movement in the silt loam in this study. In a sandier soil with poorer lateral soil water movement, intense bed drip irrigation could result in higher yields than conventional bed drip irrigation because the rows of onions are closer to the drip tapes and wetted soil volume would be more likely to reach the root plate of all bulbs, initiating new root growth and enhancing yield.

In this study, furrow-irrigated onion was just as productive as subsurface drip-irrigated onion. The lower yield expected using furrow irrigation was largely offset by the use of straw mulch in the irrigation furrows (Shock et al., 1999). With the use of short plots, it is feasible to manage uniform and precise

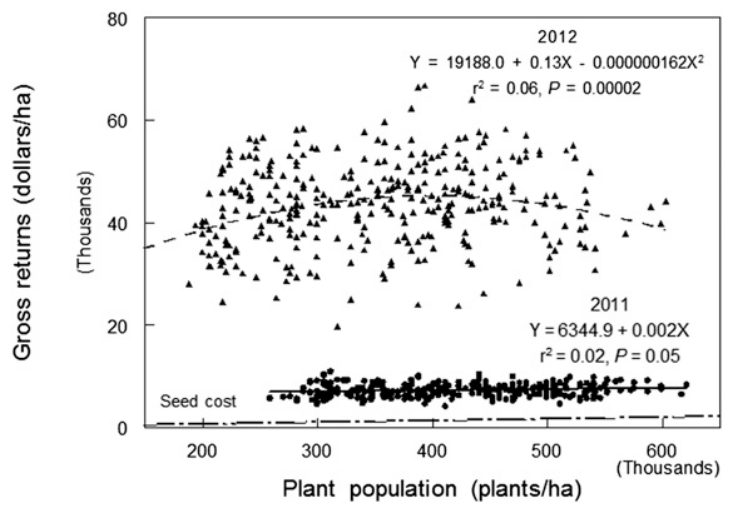

Fig. 4. Gross returns of onions grown in response to plant population for four cultivars on conventional bed configuration under drip and furrow irrigation and on intense bed configuration under drip irrigation in 2011 and 2012 at Ontario, OR. Seed costs increase with increased seed needed for direct planting. population decisions should probably be based more on growers' expected market demand for the different bulb size classes.

Other studies tested plant populations in a range higher than in our study and under different environmental conditions, making comparisons difficult. The Treasure Valley environment with high irradiance, fertile soil, and irrigation favors high productivity. Highest marketable yields in our study averaged $119 \mathrm{Mg} \cdot \mathrm{ha}^{-1}$ over the 2 years. Some studies found yield of bulbs equivalent to our marketable size class $(>57 \mathrm{~mm})$ to be maximized by plant populations lower than ours. In Poland, yield of bulbs larger than $60 \mathrm{~mm}$ was maximized at $39.6 \mathrm{Mg} \cdot \mathrm{ha}^{-1}$ by the lowest plant population tested, 400,000 plants/ha (Rumpel and Felzczynski, 2000). Their marketable yield $(>30 \mathrm{~mm})$ was maximized at $59 \mathrm{Mg} \cdot \mathrm{ha}^{-1}$ by the highest plant population tested of 800,000 plants/ha. A study from The Netherlands with a short-day onion cultivar, found yields of bulbs larger than $60 \mathrm{~mm}$ was maximized at $63.6 \mathrm{Mg} \cdot \mathrm{ha}^{-1}$ by a plant population of 200,000 plants/ha (de Visser and van den Berg, 1998), lower than in our present study. In England, Rickard and Wickens (1979) found that yield of bulbs larger than $62 \mathrm{~mm}$ was maximized at 9.9 to $10.9 \mathrm{Mg} \cdot \mathrm{ha}^{-1}$ by a plant population of 375,000 plants/ha. However, highest yields of their preferred size class $(>40 \mathrm{~mm})$ was maximized at 40 to 50 $\mathrm{Mg} \cdot \mathrm{ha}^{-1}$ with 750,000 plants/ha.

Other studies found marketable yield to be maximized by plant populations higher than ours. In California, Hatridge-Esh and Bennett (1980), using long-day onion, found that marketable yield $(>55 \mathrm{~mm})$ in dry weight was maximized by a plant population of 800,000 plants/ha. In south Australia, yield of bulbs larger than $50 \mathrm{~mm}$ was maximized at 70.6 $\mathrm{Mg} \cdot \mathrm{ha}^{-1}$ by a plant population of 750,000 to 800,000 plants/ha (Rogers, 1978). Frappell (1973) in Tasmania using intermediate maturity onions, found that marketable yield $(>50$ $\mathrm{mm}$ ) was maximized from 55 to $75 \mathrm{Mg} \cdot \mathrm{ha}^{-1}$ by 450,000 to 700,000 plants/ha depending on year. The environmental conditions and maturity type in the studies in south Australia, Tasmania, and California were more similar to the Treasure Valley of Oregon and Idaho than those in Europe. These studies suggest the possibility that marketable yield in the Treasure Valley could be maximized by plant populations higher than those tested in our study.

Rectangularity. In our study, the rectangularity, from the lowest to the highest plant population, ranged from 1.7 to 4.7 for the conventional bed and from 0.8 to 2.1 for the intense bed (Table 1). Both Frappell (1973) and Hatridge-Esh and Bennett (1980) found that increasing rectangularity was correlated with decreasing bulb yield. The differences in rectangularity among bed configurations in our study did not appear to be an important factor. Yields were similar in 2011 and slightly higher for the conventional bed than the intense bed in 2012, despite the conventional bed having much higher rectangularities. Additionally, Shock et al. (1990) did not find any effect of reductions in rectangularity on onion 
yield. Reducing the rectangularity below that of the intense bed configuration in our study might not be feasible or desirable for commercial production in the Treasure Valley.

The needs for cultivation and for either a furrow or a drip tape between onion rows place practical limits on the minimum row spacing. A drip-irrigated solid planting is not recommended, because onions growing over the drip tape were found to suffer from excess storage rot in a study with nine onion rows and three drip tapes on 2.2-m beds (Shock et al., 1997). Adding additional onion rows and drip lines (reducing the spacing between double lines) would require an increased quantity of drip tape per unit area, which would increase cost without probable increases in yield or financial return. Growers' choices of plant population need to be dependent on their marketing opportunities for specific bulb sizes. Given the weaker market for supercolossal sized bulbs, growers should increase plant populations from 266,000 to 419,000 plants per acre.

\section{Conclusions}

Onions grown at Ontario, OR responded to increased plant population with increased total, marketable, small, and medium bulb yields, irrespective of irrigation system or cultivar. Simultaneously, the yields of colossal and super colossal bulbs decreased. The response of jumbo bulb yield to plant population varied by year and irrigation system. In calculating gross economic returns, super colossal bulbs were not given any premium over colossal bulbs due to recent market trends. Gross economic returns trended slightly upward with plant population in 2011 over all cultivars and irrigation systems tested but the economic returns were offset by the higher seed costs necessary to establish higher plant stands through direct seeding. In 2012, gross economic returns reached a maximum at 419,000 plants/ha, a plant population considerably higher than used by Treasure Valley growers in the past.

\section{Literature Cited}

De Visser, C.L.M. and W. van den Berg. 1998. A method to calculate the size distribution of onions and its use in an onion growth model. Sci. Hort. 77:129-143.

Frappell, B.D. 1973. Plant spacing of onions. J. Hort. Sci. 48:19-28.

Hatridge-Esh, K.A. and J.P. Bennett. 1980. Effects of seed weight, plant density and spacing on yield responses of onion. J. Hort. Sci. 55:247252.

Rickard, P.C. and R. Wickens. 1979. Effect of row arrangement and plant population on the yield of ware sized bulb onions. Expl Hort. 31:1-9.

Rogers, I.S. 1978. The influence of plant spacing on the frequency distribution of bulb weight and marketable yield of onions. J. Hort. Sci. 53:153-161.

Rumpel, J. and K. Felczynski. 2000. Effect of plant density on yield and bulb size of direct sown onions. Acta Hort. 533:179-185.
Shock, C.C., T. Stieber, C. Stanger, and J. Ishida. 1990. Onion plant density, row spacing, and maturity group effects bulb yield and market grade. Oregon State Univ. Agr. Expt. Sta. Spec. Rpt. 862:56-68.

Shock, C.C., E.B.G. Feibert, and L.D. Saunders. 1997. Automation of subsurface drip irrigation for onion production. Oregon State Univ. Agr. Expt. Sta. Spec. Rpt. 978:42-46.

Shock, C.C., J.M. Barnum, and M. Seddigh. 1998a. Calibration of Watermark Soil Moisture Sensors for irrigation management, p. 139-146. Proc. Intl. Irr. Show, Irrigation Association, San Diego, CA.

Shock, C.C., E.B.G. Feibert, and L.D. Saunders. 1998b. Onion yield and quality affected by soil water potential as irrigation threshold. HortScience 33:1188-1191.

Shock, C.C., L.B. Johnson, J.H. Hobson, M. Seddigh, B.M. Shock, L.D. Saunders, and T.D. Stieber. 1999. Improving onion yield and market grade by mechanical straw application to irrigation furrows. HortTechnology 9:251253.

Shock, C.C., E.B.G. Feibert, and L.D. Saunders. 2000a. Irrigation criteria for drip-irrigated onions. HortScience 35:63-66.

Shock, C.C., J.K. Ishida, E.P. Eldredge, and M. Seddigh. 2000b. Yield of yellow onion cultivars in eastern Oregon and southwestern Idaho. HortTechnology 10:613-620.

Shock, C.C., E.B.G. Feibert, and L.D. Saunders. 2004. Plant population and nitrogen fertilization for subsurface drip-irrigated onion. HortScience 39:1722-1727.

Wright, J.L. 1982. New evapotranspiration crop coefficients. J. Irr. Drain. Div. 108:57-74. 